Portland State University

PDXScholar

$11-17-2017$

\title{
L2 Motivation in Japanese Elementary EFL Classrooms: a Review of the Literature
}

Cassandra Brown

Portland State University

Follow this and additional works at: https://pdxscholar.library.pdx.edu/honorstheses Let us know how access to this document benefits you.

\section{Recommended Citation}

Brown, Cassandra, "L2 Motivation in Japanese Elementary EFL Classrooms: a Review of the Literature" (2017). University Honors Theses. Paper 493.

https://doi.org/10.15760/honors.496

This Thesis is brought to you for free and open access. It has been accepted for inclusion in University Honors Theses by an authorized administrator of PDXScholar. Please contact us if we can make this document more accessible: pdxscholar@pdx.edu. 
L2 Motivation in Japanese Elementary EFL Classrooms: A Review of the Literature

by

Cassandra Brown

An undergraduate honors thesis submitted in partial fulfillment of the requirements for the degree of

Bachelor of Arts

in

University Honors

And

Arts \& Letters

Thesis Adviser

Dr. Caitlin Cole

Portland State University 


\begin{abstract}
In their formal education systems, East Asian nations began to actively incorporate English lessons around the turn of the $21^{\text {st }}$ century. For Japan, perhaps the most controversial reform was introducing compulsory English as a foreign language (EFL) instruction at the primary school level in 2011. A central policy goal specifies guidelines for encouraging positive affect and long-term motivation toward the language. In this literature review, I discuss empirical studies from within the past five years which explore Japanese elementary EFL students' motivation and engagement in class. Researchers framed their inquiry within the self-determination theory (SDT) framework, a dominant theory of motivation in language motivation research. Thus, a foundation has been set for future research by successfully establishing the validity of SDT and the concept of engagement in this context.
\end{abstract}


Multilingual language proficiencies are increasingly considered to be important for success in a globalized world, and English enjoys a prestigious status as the world's lingua franca (Sakamoto, 2012). Sharing these beliefs, many governments in East Asia have introduced English lessons into the national curriculum in order to produce a globally-competitive workforce (Butler, 2015). Indeed, many companies in Japan base decisions of recruitment and promotion partly on standardized international tests such as TOEFL (Hu 2012); Prime minister Shinzo Abe proposed these scores as criteria for entering and graduating from universities (Hongo, 2013). The reality is that Japan, as of 2016, ranks only above Afghanistan, Cambodia, and Tajikistan, and the People's Democratic Republic of Lao in Asia on TOEFL scores (“Test and Score Data," 2017).

The Japanese Ministry of Education, Culture, Sports, Science, and Technology (MEXT) provides standard contents and objectives for each school subject in the Course of Study. Japan's school system has six years of elementary, and three years of junior and senior high schools. Japanese students are often described as being competent in literacy skills, but severely lacking oral skills (Butler 2015). Following revisions in 2008, fifth and sixth graders have attended weekly compulsory English classes; each session lasts 45 minutes (MEXT). Recommendations for class structure included greetings, games, and other activities to foster a desire to use spoken English naturally. MEXT (2008) explicitly clarified goals to include development of interest, positive behavior, and long-term motivation for the language. No assessments are given in order to avoid discouraging students. Moore et al. (2015) suggests high-quality, internally-regulated motivation may be considered an appropriate outcome of the learning process, especially for elementary schools. As noted by Butler (2015 p.39), situated research on the learning context is now needed to find how best to support and maintain young learners' motivation; indeed, considerable attention to 
motivation in elementary schools across East Asia has recently accumulated. Self-determination theory (SDT) is one of the dominating theoretical frameworks of research on L2 classrooms (Lamb, 2017). Applied to education generally, SDT has shown positive explanatory power for students' desire to continue learning the new language (Noels, et al., 2000) and interact with foreign cultures (Noels et al., 2001; Vansteenkiste et al., 2005). I have collected empirical articles from within the past five years to discover how L2 motivation is conceptualized and measured in Japanese elementary English as a foreign language (EFL) classrooms.

\section{Background}

Every study included in the literature review utilizes SDT as the theoretical framework. I will describe the relevant dimensions of SDT, as they are essential to understanding research purposes and discussions.

\section{Self-Determination Theory}

Deci and Ryan (1985) and Ryan et al. (1985) developed a multi-faceted theory of human motivation under the Organismic meta-theory ${ }^{1}$. The main idea of the theory centers on the degree to which motivation is regarded as internal and how varying levels of motivation, in addition to environmental factors, influence action. Noels and colleagues (1999; 2000; 2001) led applications of SDT to L2 pedagogy in a Spanish language context. As a theoretical framework, SDT has been tested, validated, and increasingly used to study motivation in second language acquisition (SLA), is well-represented in studies of education in general (Stroet, Opdenakker, \& Minnaert 2013), and has been successfully applied to several educational settings (e.g., Fortier et al., 1995; Gottfried, 1990; Grolnick \& Ryan, 1987; Grolnick et al., 1991; Ryan \& Connell, 1989; Vallerand \& Bissonnette,

\footnotetext{
1 "People are active organisms, with evolved tendencies toward growing, mastering ambient challenges, and integrating new experiences into a coherent sense of self" ("Meta-Theory," 2017).
} 
1992). According to Reeve (2012), SDT is "a macro-theory of motivation comprised of five interrelated mini-theories." The theories relevant to this literature review are organismic integration theory, (OIT) basic psychological needs theory, (BPNT) and cognitive evaluation theory (CET) (Ryan, Deci, \& Vansteenkiste 2016).

Organismic integration theory. OIT describes a set of behavioral regulation patterns which shift along a continuum from external, controlled motives to internalized, autonomous reasons. Autonomous, or intrinsic, motivation stems from an individual's positive feelings. The individual participates in the activity for its own sake. Extrinsic motivation is determined by a source such as tangible benefits or costs, or to obtain an outcome separable from the activity itself. Four levels of extrinsic motivation have been proposed within the realm of education: introjected regulation ${ }^{2}$, identified regulation ${ }^{3}$, and integrated regulation ${ }^{4}$. Each type is more internalized into the self-concept, or self-determined, than the last. However, motivational regulations are not mutually exclusive; all may apply to a certain extent in a situation (Deci \& Ryan, 2000). Guay (2005 p.88) stated that "the adjacent subscales along the self-determination continuum were more positively correlated than those that were more distant from each other [e.g. intrinsic and extrinsic motivation]." For example, a person who is intrinsically motivated is more likely to have identified regulations than extrinsic motives. This has been replicated in naturalistic studies (Grouzet et al., 2006; Otis et al., 2005). Furthermore, quality of motivation is characterized by the degree to which a motive is internally-regulated. Theoretically and empirically, this matters more than the quantity or intensity of motivation (Vansteenkiste et al., 2009). ). That is, autonomously-motivated students achieve better

\footnotetext{
${ }^{2}$ Internal pressure as a reaction to a stimulus, such as guilt

${ }^{3}$ Self-initiation of an action accepted or owned as personally important

4 "Integration occurs when identified regulations ... have been evaluated and brought into congruence with one's other values and needs (Ryan and Deci 2000 p.73)
} 
grades (Soenens \& Vansteenkiste, 2005). Alternatively, students with more controlled motives exhibit lower achievement as well as less effective time management and greater anxiety (Senécal, Julien, \& Guay, 2003).

Evidence in support for OIT has been shown in a foreign language learning context (Noels et al., 1999, 2000, 2001), in a Japanese EFL context (Hiromori, 2006; Honda and Sakyu, 2004; Tanaka, 2009), and in Japanese elementary schools (Ando, Fuse, \& Kodaira, 2008; Yamauchi \& Tanaka, 1998). Only one assessment of L2 motivational orientations based on SDT of Japanese EFL students has been done (Carreira, 2011).

SDT posits that internally-regulated motivations are influenced by the interaction between the environment and the self.

Basic psychological needs theory. This mini-theory is conceptualized under the assumption that human beings thrive under situations where their basic psychological needs are met; social factors fulfilling or thwarting these needs can influence more or less self-determined forms of motivation (Standage et al., 2005). These needs are necessarily interrelated, and in most contexts highly correlated (Deci \& Ryan 2000). Autonomy is a sense of personal causality and feelings of volition in one's actions (Deci \& Ryan, 2000; deCharms, 1968). Competence is the sense of propensity to experience challenge and mastery in one's activities (White, 1959). Relatedness is the need to feel a connection to others, a group, or a culture, and form strong and stable interpersonal bonds (Baumeister \& Leary, 1995; Ryan \& Deci, 2000).

Indeed, multiple studies have connected need satisfaction and motivation, particularly autonomous motivation, in contexts such as education (Ntoumanis, 2001; Reinboth et al., 2004; Standage et al., 2003, 2005; Vallerand et al., 1997) and various language learning settings (McEown, 
Noels, \& Saumure, 2014; Noels, 2013). Cognitive Evaluation Theory provides a mechanism by which students' needs may be met by the environment (Skinner et al., 2008)

Cognitive evaluation theory. As Deci et al. (2011) puts it, teachers may direct and control student through rewards and punishments, or may focus on providing students with the resources to feel initiative and choice by focusing on autonomy support. As described by Reeve (2012), “autonomy-support is whatever a teachers says and does during instruction to facilitate students' perceptions of autonomy and experiences of psychological need satisfaction" (p. 167). Under this definition, cultural interpretations and adaptations are possible, while retaining the idea that supporting basic psychological needs is vital for good teaching. For instance, because autonomy does not require "independence," teacher support of learner autonomy remains a key factor in collectivist settings (Jang et al., 2009). Indeed, the importance of autonomy-supportive environments has been demonstrated (Noels, 2001; Noels et al., 1999; Wu, 2003).

Another facet of supporting students' needs relates to structure, or the form that instruction takes. Structured teaching is clear, well-organized, appropriately paced, provides feedback, and builds new knowledge (Jang, Reeve, \& Deci, 2010). According to SDT, when a teacher supports learners' needs through the use of interesting activities or culturally-appropriate expectations (Reeve 2012), they cultivate more self-determined forms of motivation. Where motivation is the potential and direction of one's energy, engagement is that energy being used.

\section{Engagement}

Outlined by Fredricks et al. (2004), engagement is a multi-faceted concept; it is an observable state (Lee \& Reeve, 2012) and a process describing student behavior, cognition, and emotions in class. Theoretical and empirical work identifies several overlapping aspects of engagement (Fredricks 
et al., 2004; Reeve, 2012; Svalberg, 2009). For instance, behavioral engagement is represented by students being on task and completing assignments. Cognitive and social components include attention and interaction. When teachers talk about a desire to motivate students, they may actually be expressing the desire to help students actively engage. So, teachers may be more able to recognize engagement than motivation (Lee \& Reeve, 2012).

The concept of engagement is compatible with multiple motivational frameworks; researchers have integrated SDT concepts including BPNT, structure, and support with engagement (Jang et al., 2009, 2010, 2012; Skinner et al., 2008, etc.). As a key step in the process of foreign language learning (Dörnyei \& Ryan, 2015; Svalberg, 2009), engagement is important for promoting achievement, learning, and long-term motivation (Reeve 2012; Hyland, 2003; Reeve \& Lee, 2014; Reeve \& Tseng, 2011). Furthermore, engagement has been measured using self-report (Reeve \& Tseng, 2011), external rating (Jang, Reeve, \& Deci, 2010), and a combination (Skinner et al., 2008). Lee and Reeve (2014) found a potentially reciprocal relationship between engagement and motivation, among other internal states. While engagement is dependent on motivation, it may also predict motivation. Research by Hyland (2003; Lo \& Hyland, 2007) has shown that engagement with learning material leads to an increase in motivation and development in ability; accordingly, engagement is a reliable predictor of achievement in first language studies (Jang et al., 2009, 2012).

\section{Literature Review}

The goal of this literature review is to analyze research purposes, processes, and findings of a group of empirical articles which study motivation in Japanese elementary EFL classrooms. The first major goal is to replicate and validate fundamental tenets of SDT, outlined above, in an unexplored context. With that accomplished, they aim to assess and investigate student motivation, since it is a 
primary concern for educators and policymakers. Pedagogical implications will be discussed in the conclusion.

\section{Motivation Regulations}

Adjacent constructs. Results were mixed on whether the continuum of self-determination is recognized as a three (Carreira 2012; Ando et al. 2008) or four-factor (Oga-Baldwin \& Nakata, 2017; Yamauchi \& Tanaka, 1998) construct among Japanese elementary EFL students. Ando et al. (2008) investigated motivation for learning mathematics and Japanese among elementary students in third through sixth grades; the exploratory factor analysis revealed three orientations:

high-autonomous extrinsic motivation, low-autonomous extrinsic motivation, and intrinsic motivation. Using a survey based on this experiment and exploratory factor analysis, Carreira (2012) replicated this continuum with fifth and sixth grade Japanese EFL students (10-12 years). Specifically, introjected and identified regulations were combined. Another cross-sectional assessment of fifth graders used the Self-Regulation Questionnaire - Academic: SRQ-A (Ryan \& McConnell 1989; Noels et al., 2000; Yamauchi \& Tanaka, 1998), and found that the EFL students recognized the four basic types of motivational regulation as "distinct and comprehensible" (Oga-Baldwin \& Nakata, 2017). Regardless, the patterns of correlations were largely consistent with OIT in assessments of motivational orientation; as expected, the relationship between motivational regulations and level of basic psychological need satisfaction followed the continuum of self-determination.

Need satisfaction. There is strong convergent evidence confirming that autonomous motivation is an outcome of need satisfaction, although there are a few discrepancies on the relative influence of autonomy and relatedness. Based on previous studies (Hiromori. 2006; Wu, 2003), 
Carreria (2012) assessed perceptions of autonomy, relatedness, and competence (ARC) of 505 EFL students in Tokyo. With the same instruments, Carreira et al. (2013) conducted another cross-sectional study, measuring just intrinsic motivation and need satisfaction of a smaller, but wider sample of third through sixth graders. Unlike Hiromori (2006, p.73), who that found relatedness was negatively related to external, Carreira found relatedness unrelated to external regulation (2012). While Carreira (2012) found that relatedness was the strongest correlate to intrinsic motivation, the 2013 study found that relatedness had the least effect on intrinsic motivation (Carreira et al.). In addition, unlike Noels et al. (2000), Carreira (2012) found that that autonomy was negatively correlated with external regulation, instead of unrelated. Within both studies, perception of competence was positively correlated with more self-determined forms of motivation, confirming Vallerand and Reid (1984). Deci and Ryan (1985) argued that the relative impact of each psychological mediator varies depending on the functional significance of the situation. For example, no previous reports in the relevant literature described the different degrees to which psychological needs influence motivational orientations according to age.

Age differences. There is a lack of consensus on whether developmental trends in intrinsic motivation exist among Japanese elementary EFL students, although age differences have been observed (Carreira et al. 2013). For students of higher grades (fifth and sixth), perceptions of competence were more positively correlated with intrinsic motivation than for students of middle grades (third and fourth); this suggests that feeling competent in English lessons becomes more important as students age (Carreira et al., 2013). For middle grades, intrinsic motivation had higher coefficients with autonomy support. 
Oga-Baldwin et al. (2017) was the first to incorporate all three mini-theories of SDT in an empirical longitudinal model. Previous longitudinal models of motivational development in L1 and L2 educational settings mainly focused on secondary school students (e.g., Csizér \& Dörnyei, 2005; Jang, Kim, \& Reeve, 2012). Although evidence for discriminant validity between intrinsic and identified regulation exists for the same context (Oga-Baldwin \& Nakata, 2017), this study used a single latent factor of autonomous motivation to avoid difficulties with highly-correlated predictors.

Prior motivation was measured at the beginning of the school year, and outcome motivation refers to the three regulations at the end of the year. While Carreira $(2011 ; 2012)$ indicates a clear pattern of decreasing motivation between fifth and sixth graders, the cross-sectional nature of the model makes it difficult to confirm a developmental trend; it may be attributed to teaching and the classroom environment. Students in Oga-Baldwin's sample did not show decreases in quality of motivation over time, providing further evidence of motivational stability (Nakata 2006). Moreover, existing motivation significantly, sometimes strongly, predicted itself.

Oga-Baldwin and Nakata's (2015) series of longitudinal studies reinforced this idea; students' perception of competence had the strongest influence of measurement of competence at the end of the year. Autonomy and relatedness demonstrated a weaker, although still significant, auto-regressive influence over time, but did not have predictive effects (Oga-Baldwin \& Nakata, 2015). With prior motivation, findings by Oga-Baldwin et al. (2017) indicate that more internally-regulated students form a more positive picture of teacher support. Vallerand (1997, p. 299) suggested that that social factors such as autonomy-supportive or controlling teaching styles can influence motivation orientations through satisfaction of fundamental needs.

\section{Teacher Autonomy-support and Structure}


Need satisfaction. Carreira et al. (2013) and Oga-Baldwin et al. (2015; 2017) agree that teacher autonomy support significantly predicts student perceptions of ARC, and therefore autonomous motivation. However, Oga-Baldwin and Nakata (2015) raised issues of discriminant validity of between autonomy-support and structure for teaching Japanese EFL classes, and argued for a conceptual adjustment of autonomy; in a series of studies, a new questionnaire for teacher supportive-structure was developed with focus groups, and tested for external validity twice over two semesters cross-sectionally.

Although items on the measure clearly differentiated predictor (teacher) and outcome (self) variables, students and teachers agreed that common instruments were unclear or didn't match the setting properly. While Carreira (2012; et al. 2013) uses the traditional sense of autonomy as a sense of ownership in the learning process, Oga-Baldwin and Nakata (2015) argue teacher support for autonomy is not best defined as opportunities for individual decision-making. They argue structure and autonomy support should be combined because of how they function in a Japanese classroom setting; form and structure of lessons are an integral part of the motivational process. Regardless of which instrument was used ${ }^{5}$, teacher support strongly predicted need satisfaction (Oga-Baldwin et al. 2015, 2017; Carreira 2013). Carreira et al. (2013) established an indirect path of teacher autonomy-support to autonomous motivation through fulfillment of ARC.

Engagement. Oga-Baldwin et al. $(2015 ; 2017)$ replicated the validity of the supportive-structure teaching measure and demonstrated a predictive relationship of the environment and students' in-class engagement. Oga-Baldwin et al. (2017) measured engagement as a single latent factor, while Oga-Baldwin and Nakata (2015) focused on behavioral engagement.

\footnotetext{
${ }^{5}$ Carreira et al. (2013) measured autonomy-support with the Learning Climate questionnaire (Black and Deci, 2000).
} 
Longitudinally, autonomy has been shown to mediate the influence of the classroom on student engagement and achievement (Jang et al., 2012). Research into supportive teaching has used engagement as a dynamic pivot point in the process of classroom motivational growth (cf. Jang et al., 2012; Skinner et al., 2008)

\section{Engagement}

Motivation regulations. Oga-Baldwin and Nakata $(2015 ; 2017)$ used aspects of the self-determination continuum to replicate a positive relationship between engagement and different motivational regulations (Reeve and Lee, 2014); Oga-Baldwin and Nakata (2015) longitudinally supported engagement as a mediator of the influence of classroom environment and prior motivation on future motivation (Heckhausen, 1991; Reeve \& Lee, 2014).

According to recent theory (Reeve, 2012), engagement should positively support and maintain students' motivation over time. Engagement alone did not predict motivation

(Oga-Baldwin et al. 2017); this indicates that engagement is situational, and connected with quality of classroom environment more than student motivation. Oga-Baldwin and Nakata's cross-sectional model (2015) measured engagement at the beginning of the semester, and motivation regulations at the end. This indicates that students who actively engage in foreign language learning are also more motivated at the end of the term. The 2017 study also showed that engagement may positively predict more autonomous motivation, while negatively predicting more controlled motives (Oga-Baldwin and Nakata); autonomous motivations increased proportionally to engagement. Oga-Baldwin et al. conducted the only studies to utilize external observation and an outcome measure in Japanese elementary EFL classrooms (2017)

\section{Teacher Assessment and External Observations of Engagement}


The self-report model was validated by confirming that self-reported engagement is visible to external raters (Butler \& Lee, 2006; Lee \& Reeve, 2012), but effects were small when it came to the ability of homeroom teachers to understand students' self-reported motivation and engagement (Oga-Baldwin \& Nakata 2017; Oga-Baldwin et al. 2017). Different rating systems were used, and teachers took a survey at the end of the semester to assess an individual's in-class interest, behavior, motivation, and English ability. Although subjective, constraints on the use of testing in elementary EFL classes made outcome measures tricky. The findings were consistent with the relationship between engagement, motivation, and assessment in other longitudinal studies of engagement (Jang et al., 2012; Reeve \& Lee, 2014).

\section{Conclusion}

In these studies, motivational orientations and basic psychological needs satisfaction of elementary students were assessed first. As SDT predicts, students were more likely to be intrinsically motivated when they perceived the classroom environment as fulfilling their needs for autonomy, competence, and relatedness. Next, researchers examined the role of teachers. An indirect, but significant, path was shown from autonomy-support to intrinsic motivation through satisfaction of psychological needs. A significant and potentially reciprocal relationship was found between engagement, the classroom environment, and motivation. Finally, outcome measures were explored in an effort to reconcile the issue of testing in Japanese elementary EFL classes. Now I will go into detail about the pedagogical implications of this research.

\section{Pedagogical Implications}

There is already sufficient evidence to suggest that language teachers are able to influence learners' motivation for better and for worse (Lamb, 2017). 
First, Carreira (2012; Carreira et al. 2013) found evidence for a path from teacher autonomy-support to autonomous motivation through students' perceptions of need satisfaction. Dörnyei (2001 p.90) suggests providing multiple opportunities for success in the classroom and adjust difficulty level of tasks to student abilities. According to Furrer and Skinner (2003), relatedness can be fostered through genuine interpersonal involvement with teachers .

Next, Oga-Baldwin and Nakata (2015) also found that the classroom environment, created by well-structured and supportive teaching, predicts student perceptions of need satisfaction and behavioral engagement. This was reinforced in the 2017 study with a more broad construct of engagement, suggesting that engagement may help support and maintain autonomous motivation long-term. Together, forms of engagement have shown meaningful effects on achievement (Jang et al., 2012, 2016).

Reeve et al. (2004 p.53) wrote, the key question teachers need to ask themselves is not "how can I motivate my students?" but "how can I create the conditions under which students will be able to motivate themselves?" Given that behavior and enjoyment are specifically mentioned in the Course of Study, this body of literature appropriately tested the validity of a psychological theory of motivation by applying SDT's precepts in EFL elementary classrooms. The majority of the information on young learners' foreign language education comes from either L2 context among immigrant and language-minority children, primarily in English-speaking contexts, or FL context in Europe (Lamb, 2017). Now I will suggest how researchers could build on this literature in the context of Japanese elementary EFL classrooms.

\section{Future Research}


Much of the data was obtained through surveys. As Oga-Baldwin and Nakata (2015) addressed, items used in the supporting literature were often decontextualized and potentially confusing for children. Researchers should work on establishing standard measures for this context, and this work is in progress thanks to focus groups of teachers and students. Engagement should continue to be considered an integral aspect of a dynamic process toward motivational development. Perhaps the most problematic issue of future research is evaluation; there are no systematic measures for evaluating children's language learning or program effectiveness that correspond to the MEXT objectives. These existing studies did not qualitatively investigate external rater observations; this avenue, as well as interviews, should be explored.

While motivation may fluctuate over time (Dörnyei, Ibrahim, \& Muir, 2015), findings in this body of literature indicate that changes in motivation may be connected to stable beliefs influencing student behavior indirectly. These beliefs should be investigated; the concept of a stable core of motivation (Nakata, 2006); the presence of a sense of autonomous motivation to learn beyond simple enjoyment. It is also important to continue questioning whether the complex nature of demotivation remains the same across age groups; responses may be interpreted differently depending on age. Longitudinal models have been the minority so far, but they should be utilized to explore possible developmental trends. Future research could also investigate the mechanism of demotivation, and potential instructional strategies. 


\section{References}

Ando, F., Fuse, M., \& Kodaira, H. (2008). Motivation and elementary school pupils’ positive class participation: Self-determination theory. Japanese Journal of Educational Psychology, 56(2), 160_ 170.

Baumeister, R., \& Leary, M. R. (1995). The need to belong: Desire for interpersonal attachments as a fundamental human motivation. Psychological Bulletin, 117(3), 497-529.

Black, A.E., Deci, E.L. (2000). The effects of instructors' autonomy support and students autonomous motivation on learning organic chemistry: a self-determination theory perspective. Sci. Edu. 84, 740-756.

Butler, Y.G. (2007). Factors associated with the notion that native speakers and the ideal language teachers: an examination of elementary school teachers in Japan. JALT J. 29, 7-40.

Butler, Y. (2015). English language education among young learners in East Asia: A review of current research (2004-2014). Lang. Teach. 48(3), 303-342.

Butler, Y. G., \& Lee, J. (2006). On-task versus off-task self-assessments among Korean elementary school students studying English. Modern Language Journal, 90(4), 506-518.

Carreira, J.M. (2011). Relationship between motivation for learning EFL and intrinsic motivation for learning in general among Japanese elementary school students. System 39, 90-102.

Carreira, J.M. (2012). Motivational orientations and psychological needs in EFL learning among elementary school students in Japan. System 40, 191-202.

Carreira, J. M., Ozaki, K., \& Maeda, T. (2013). Motivational model of English learning among elementary school students in Japan. System, 41(3), 706-719. 
Csizér, K., \& Dörnyei, Z. (2005). Language learners' motivational profiles and their motivated learning behavior. Language Learning, 55(4), 613-659.

deCharms, R. (1968). Personal causation: The internal affective determinants of behavior. New York: Academic Press.

Deci, E. L., \& Ryan, R. M. (1985). Intrinsic motivation and self-determination in human behavior. NY: Plenum.

Deci, E. L., \& Ryan, R. M. (2000). The “what" and 'why' of goal pursuits: Human needs and the self-determination of behavior. Psychological Inquiry, 11(4), 227-268.

Deci, E. L., Koestner, R., \& Ryan, R. M. (2001). Extrinsic rewards and intrinsic motivation in education: Reconsidered once again. Review of Educational Research, 71(1), 1-27.

Dörnyei, Z. (2001). Motivational Strategies in the Language Classroom. Cambridge: Cambridge University Press.

Dörnyei, Z., \& Ryan, S. (2015). The psychology of the language learner revisited. New York: Routledge.

Dörnyei, Z., Ibrahim, Z., \& Muir, C. (2015). 'Directed motivational currents': Regulating complex dynamic systems through motivational surges. In Z. Dörnyei, P. MacIntyre, \& A. Henry (Eds.), Motivational dynamics in language learming (pp. 95-105). Bristol: Multilingual Matters.

Fredricks, J. A., Blumenfeld, P. C., \& Paris, A. H. (2004). School engagement: Potential of the concept, state of the evidence. Review of Educational Research, 74(1), 59-109.

Fortier, M., Vallerand, R., Guay, F. (1995). Academic motivation and school performance: toward a structural model. Contemporary Educational Psychology 20, 257-274.

Furrer, C., Skinner, E. (2003). Sense of relatedness as a factor in children's academic engagement and performance. Journal of Educational Psychology 95, 148-162. 
Gardner, R., Lambert, W. (1972). Attitudes and Motivation in Second Language Learning. Newbury House, Rowley, MA.

Gottfried, A. (1990). Academic intrinsic motivation in young elementary school children. Journal of Educational Psychology 82, 525-538.

Grolnick, W., Ryan, R. (1987). Autonomy in children’s learning: an experimental and individual difference investigation. Journal of Personality and Social Psychology 52, 890-898.

Grolnick, W.S., Ryan, R.M., Deci, E.L. (1991). Inner resources for school achievement: motivational mediators of children's perceptions of their parents. Jourmal of Educational Psychology 83, 508517.

Grouzet, F., Otis, N., Pelletier, L. (2006). Longitudinal cross-gender factorial invariance of the academic motivation scale. Structural Equation Modeling 13, 73-98.

Guay, F. (2005). Motivations underlying career decision-making activities: the career decisionmaking autonomy scale (CDMAS). Journal of Career Assessment 13, 77-97.

Heckhausen, H. (1991). Motivation and action. Berlin: Springer-Verlag.

Hiromori, T. (2006). The effects of educational intervention on L2 learners' motivational development. JACET Bull. 43, 1-14.

Honda, K., Sakyu, M. (2004). Multiple models of motivation for Japanese EFL learners: an investigation into concepts in different paradigms. Annual Review of English Language Education in Japan. 15, 41-50.

Hongo, J. (2013, Mar 25). Abe wants TOEFL to be key exam. The Japan Times. Retrieved from https://www.japantimes.co.jp/news/2013/03/25/national/abe-wants-toefl-to-be-keyexam/\#.Wiu34lWnGUl/ 
Hu, G., McKay, S. L. (2012). English language education in East Asia: some recent developments. Journal of Multilingual and Multicultural Development, 33(4) 345-362.

Hyland, F. (2003). Focusing on form: Student engagement with teacher feedback. System, 31(2), $217-$ 230.

Jang, H., Reeve, J., Ryan, R. M., \& Kim, A. (2009). Can self-determination theory explain what underlies the productive, satisfying learning experiences of collectivistically oriented Korean students? Journal of Educational Psychology, 101(3), 644-661.

Jang, H., Reeve, J., \& Deci, E. L. (2010). Engaging students in learning activities: It is not autonomy support or structure but autonomy support and structure. Journal of Educational Psychology, 103(2), 588-600.

Jang, H., Kim, E. J., \& Reeve, J. (2012). Longitudinal test of self-determination theory's motivation mediation model in a naturally occurring classroom context. Journal of Educational Psychology, 104(4), 1175-1188.

Jang, H., Kim, E. J., \& Reeve, J. (2016). Why students become more engaged or more disengaged during the semester: A self-determination theory dual-process model. Learning and Instruction, $1-12$.

Lamb, M. (2017). The motivational dimension of language teaching. Lang. Teach. 50(3), 301-346.

Lee, W., \& Reeve, J. (2012). Teachers' estimates of their students' motivation and engagement: Being in synch with students. Educational Psychology, 32(6), 727-747.

Lo, J., \& Hyland, F. (2007). Enhancing students' engagement and motivation in writing: The case of primary students in Hong Kong. Journal of Second Language Writing, 16(4), 219-237. 
“Meta-Theory: The Organismic Viewpoint.” (2017). Retrieved from http://selfdeterminationtheory.org/meta-theory-the-organismic-viewpoint/

MEXT. (2008). Shogakkou gakushuu shidou youryou kaisetu: Gaikokugo katsudouhen [Explanatory commentary for the elementary school curriculum guidelines: Foreign language activities]. Retrieved from http://www.mext.go.jp/component/a_menu/education/micro_detail/_icsFiles/afieldfile/ 2009/06/16/1234931_012.pdf/.

McEown, M. S., Noels, K. A., \& Saumure, K. D. (2014). Self-determined and integrative orientations and teachers' motivational support in a Japanese as a foreign language context. System, 1-15.

Moore, K. A., Lippman, L. H., \& Ryberg, R. (2015). Improving outcome measures other than achievement. AERA Open, 1(2).

Nakata (2006). Motivation and experience in foreign language learming. Bern: Peter Lang.

Noels, K. A. (2001). Learning Spanish as a second language: Learners' orientations and perceptions of their teachers' communicative style. Language Learning 51, 107-144.

Noels, K. A., Clément, R., \& Pelletier, L. G. (1999). Perceptions of teachers’ communicative style and students' intrinsic and extrinsic motivation. The Modern Language Journal, 83(1), 23-34.

Noels, K. A., Pelletier, L. G., Clément, R., \& Vallerand, R. J. (2000). Why are you learning a second language? Motivational orientations and self-determination theory. Language Learning, 50(1), 57-85.

Noels, K. A., Clément, R., \& Pelletier, L. G. (2001). Intrinsic, extrinsic, and integrative orientations of French Canadian learners of English. Canadian Modern Language Review, 57(3), 424-442. 
Noels, K. A. (2013). Promoting the motivation of Japanese learners of English through autonomy, competence, and relatedness. In M. T. Apple, D. Da Silva, \& T. Fellner (Eds.), Language learning motivation in Japan (pp. 15-34). Bristol, UK: Multilingual Matters.

Ntoumanis, N. (2001). A self-determination approach to the understanding of motivation in physical education. Br. J. Educ. Psychol. 71, 225-242.

Oga-Baldwin, W. L. Q., \& Nakata, Y. (2015). Structure also supports autonomy: Measuring and defining autonomy-supportive teaching in Japanese elementary foreign language classes. Japanese Psychological Research, 57(3), 167-179.

Oga-Baldwin, W. L. Q., \& Nakata, Y. (2017). Engagement, gender, and motivation: A predictive model for Japanese young language learners. System, 65, 151-163.

Oga-Baldwin, W. L. Q., Nakata, Y., Parker, P., \& Ryan, R. (2017). Motivating young language learners: A longitudinal model of self-determined motivation in elementary school foreign language classes. Contemporary Educational Psychology, 49, 140-150.

Otis, N., Grouzet, F., Pelletier, L.G., 2005. Latent motivational change in an academic setting: a 3year longitudinal study. Journal of Educational Psychology 97, 170-183.

Reeve, J. (2012). A self-determination theory perspective on student engagement. In S. L.

Christenson, A. L. Reschly, \& C. Wylie (Eds.), Handbook of research on student engagement (pp.149-172). Boston, MA: Springer.

Reeve, J., E. L. Deci \& R. M. Ryan (2004). Self-determination theory: A dialectical framework for understanding sociocultural influences on student motivation. In D. McInerney \& S. Van Etten (eds.), 31-60. 
Reeve, J., \& 'Tseng, C.-M. (2011). Agency as a fourth aspect of students' engagement during learning activities. Contemporary Educational Psychology, 36(4), 257-267.

Reeve, J., \& Lee, W. (2014). Students' classroom engagement produces longitudinal changes in classroom motivation. Journal of Educational Psychology, 106(2), 527-540.

Reinboth, M., Duda, J.L., Ntoumanis, N., 2004. Dimensions of coaching behavior, need satisfaction, and the psychological and physical welfare of young athletes. Motivation \& Emotion 28, 297313.

Ryan, R.M., Connell, J.P., Deci, E.L., (1985). A motivational analysis of self-determination and selfregulation in education. In: Ames, C., Ames, R.(Eds.), Research on Motivation in Education. The Classroom Milieu, vol. 2 (pp. 13-51). New York: Academic Press

Ryan, R. M., \& Connell, J. P. (1989). Perceived locus of causality and internalization: Examining reasons for acting in two domains. Journal of Personality and Social Psychology, 57, 749-761.

Ryan, R. M., \& Deci, E. L. (2002). An overview of self-determination theory: An organismicdialectical perspective. In E. L. Deci \& R. M. Ryan (Eds.), Handbook of self-determination research (pp. 3-33). Rochester, NY: University of Rochester Press.

Ryan, R. M., Deci, E. L., \& Vansteenkiste, M. (2016). Autonomy and autonomy disturbances in selfdevelopment and psychopathology: Research on motivation, attachment, and clinical process. Developmental Psychopathology.

Sakamoto, M. (2012). Moving towards effective English language teaching in Japan: issues and challenges. Journal of Multilingual and Multicultural Development, 33(4), 409-420.

Senécal, C., Julien, E., \& Guay, F. (2003). Role conflict and academic procrastination: A selfdetermination perspective. European Journal of Social Psychology, 33(2), 135-145. 
Skinner, E. A., \& Belmont, M. J. (1993). Motivation in the classroom: Reciprocal effects of teacher behavior and student engagement across the school year. Journal of Educational Psychology, $85(4), 571-581$.

Skinner, E. A., Furrer, C. J., Marchand, G., \& Kindermann, T. (2008). Engagement and disaffection in the classroom: Part of a larger motivational dynamic? Journal of Educational Psychology, 100(4), 765-781.

Standage, M., Duda, J.L., Ntoumanis, N. (2003). A model of contextual motivation in physical education: using constructs from self-determination and achievement goal theories to predict physical activity intentions. Journal of Educational Psychology 95, 97-110.

Standage, M., Duda, J.L., Ntoumanis, N. (2005). A test of self-determination theory in school physical education. British Journal of Educational Psychology 75, 411-433.

Stroet, K., M.-C. Opdenakker \& A. Minnaert (2013). Effects of need supportive teaching on early adolescents' motivation and engagement: A review of the literature. Educational Research Review 9(0), 65-87.

Svalberg, A. M.-L. (2009). Engagement with language: Interrogating a construct. Language Awareness, $18(3-4), 242-258$.

Tanaka, H. (2009). Enhancing intrinsic motivation at three levels: the effects of motivational strategies. JALT Journal 31, 227-250.

“Test and Score Data Summary for TOEFL iBT Tests.” 2017, https://www.ets.org/s/toefl/pdf/94227_unlweb.pdf.

Ushioda, E. (2011). Language learning motivation, self and identity: current theoretical perspectives. Computer Assisted Language Learning, 24(3), 199-210. 
Vallerand, R.J., 1997. Toward a hierarchical model of intrinsic and extrinsic motivation. In: Zanna, M.P. (Ed.), Advances in Experimental Social Pychology. (pp. 271-360). New York: Academic Press

Vallerand, R.J., Reid, G. (1984). On the causal effects of perceived competence on intrinsic motivation: a test of cognitive evaluation theory. Joumal of Sport Psychology 6, 94-102.

Vallerand, R.J., Bissonnette, R., 1992. Intrinsic, extrinsic, and amotivational styles as predictors of behavior: a prospective study. Journal of Personality 60, 599-620.

Vallerand, R.J., Fortier, M.S., Guay, F. (1997). Self-determination and persistence in a real-life setting: toward a motivational model of high school dropout. J. Pers. Soc. Psychol. 72, 1161 1176.

Vansteenkiste, M., Zhou, M., Lens, W., \& Soenens, B. (2005). Experiences of autonomy and control among Chinese learners: Vitalizing or immobilizing? Journal of Educational Psychology, 97(3), 468-483.

Vansteenkiste, M., Sierens, E., Soenens, B., Luyckx, K., \& Lens, W. (2009). Motivational profiles from a self-determination perspective: The quality of motivation matters. Journal of Educational Psychology, 101(3), 671-688.

White, R. W. (1959). Motivation reconsidered: The concept of competence. Psychological Review, 66(5), 297-333.

Wu, X. (2003). Intrinsic motivation and young language learners: the impact of the classroom environment. System 31, 501-517.

Yamauchi, H., \& Tanaka, K. (1998). Relations of autonomy, self-referenced beliefs, and selfregulated learning among Japanese children. Psychological Reports, 82(3), 803-816. 